\title{
Methylated polybenzimidazole and its application as a blend component in covalently cross-linked anion-exchange membranes for DMFC
}

\author{
Anika Katzfuß ${ }^{1}$, Simon Poynton ${ }^{2}$, John Varcoe $^{2}$, Viktor Gogel ${ }^{3}$, Ulrich Storr ${ }^{3}$, Jochen Kerres ${ }^{1,4}$ \\ ${ }^{1}$ Institute of Chemical Process Engineering, University of Stuttgart, Stuttgart, Germany \\ ${ }^{2}$ Department of Chemistry, University of Surrey, Guildford GU2 7KH, United Kingdom \\ ${ }^{3}$ Center for Solar Energy and Hydrogen Research (ZSW), Ulm, Germany \\ ${ }^{4}$ North-West University, Chemical Resource Beneficiation, Potchefstroom 2520, South Africa
}

Corresponding author: J. Kerres (E-mail: jochen.kerres@icvt.uni-stuttgart.de)

tel.: +49-71168585228; fax: +49-71168585242)

\begin{abstract}
In the present work, the development and characterization of new anion exchange membranes (AEM) based on a methylated polybenzimidazole (mPBIOO) and their application in direct methanol fuel cell (DMFC) is described. For the preparation of methylated PBIOO (mPBIOO), a gentle methylation method was developed by using dimethyl carbonate (DMC) and 1,4-diazabicyclo[2.2.2] octane (DABCO). The synthesis of covalent cross-linked AEMs was achieved using the mPBIOO, sulfinated polysulfone (PPSU-SO $\left.{ }_{2} \mathrm{Li}\right), \mathrm{DABCO}$ and diiodobutane (DIB). The AEMs had IECs of more than $2.0 \mathrm{meq} \mathrm{g}^{-1}$, which indicates a high concentration of anion-exchange groups. Depending on the cross-linking degree, the methanol gravimetric uptake reached a maximum of 43\%(by mass) and all AEMs showed an excellent ex situ alkaline stability. After 10 days in aqueous $\mathrm{KOH}(1 \mathrm{M})$ at $90^{\circ} \mathrm{C}$ the IECs, ionic conductivities, and mechanical stabilities did not show a significant decrease. DMFC measurements show a performance improvement of a factor of three when the membranes were solvent (dimethylacetamide) extracted before integration into the fuel cell. With the using of non-Pt catalysts, a maximum power density of $120 \mathrm{~mW} \mathrm{~cm}^{-2}$ was achieved.
\end{abstract}

\section{Keywords:}


Anion-exchange membrane, covalent cross-linking, polybenzimidazole PBIOO, direct methanol fuel cell, alkaline stability

\section{Introduction}

The use of anion-exchange membranes (AEM) in electrochemical systems is a growing research field. They are routinely applied in electrodialysis, desalination, waste water treatment, and microfiltration systems [1-4]. In the last decade a new focus on the application of AEMs in alkaline fuel cells has been established. A primary advantage with the use of generic alkaline fuel cells (AFCs) is the possibility of using non precious (platinum-free) metal catalysts [5-9]. There are, of course, disadvantages with the use of AFCs, such as the formation of carbonate species $\left(\mathrm{CO}_{3}{ }^{2-}\right.$ and $\left.\mathrm{HCO}_{3}{ }^{-}\right)$in the fuel cell, which risk the formation of precipitates in the electrodes [10-13]. It is difficult to compare the performance of AFCs containing AEMs (AEMFC) to the acidic analogue proton-exchange membrane fuel cells (PEMFC). One reason for this is that the equivalent conductivity of a $\mathrm{OH}^{-}$ion is roughly half that of a $\mathrm{H}^{+}$ion [14]. Therefore, the conductivities of AEMs can be significantly lower than those of proton-exchange membranes (PEM) at equivalent ion-exchange capacities and this is a major reason why the performances of AEMFCs are lower than PEMFCs.

During the last decade, a lot of different classes of AEMs have been studied using polymers based on poly(2,6-dimethyl-1,2-phenylenoxide) (PPO), chloromethylstyrene, divinylbenzene, poly(ethylene-co-tetrafluoroethylene)-g-poly(vinylbenzylchloride), and poly(vinylalcohol)-poly(1,3-diethyl-1-vinylimidazolium) bromide [15-22]. To introduce the anion-exchange groups (e.g. quaternary trialkylammonium groups) the precursor polymers or membranes are reacted with different amines such a trimethylamine, triethylamine or tributylamine [4, 23-25]. Diamines such as 1,4-diazabicyclo[2.2.2]octane (DABCO) or $N, N, N^{\prime}, N^{\prime}$-tetramethylhexanediamine (TMHDA) [2, 25-28] can be used to form quaternary ammonium groups and covalent cross-linking in the AEM in a single step. In all this types of AEMs, the positive charged ion is tethered to the side chain of the polymer. Frequently, these AEMs are not particularly (chemically) stable in alkaline environments especially with operation temperatures higher than $60^{\circ} \mathrm{C}$. To overcome this drawback, bulky ammonium groups can be introduced that yield additional steric hindrance or ammonium groups without $\beta-H$ atoms can be used (eliminate the possibility that the very facile Hoffmann Elimination based degradation can occur) $[29,30]$. 
There are fewer studies, however, which concentrate on AEMs where the positive ions are part of the main chain of the polymer system being used. A suitable polymer for such a system type is polybenzimidazole (PBI). It is known from the PEMFC research that PBI has extraordinary properties (high thermal, chemical and mechanical stability) and so this suggests that PBI should be also applicable for use in AEMFCs. In this respect, PBI has been doped with $\mathrm{KOH}$ and applied in this form to fuel cells [31-33]. Due to the risk of losing $\mathrm{KOH}$ content via the washing-out of $\mathrm{KOH}$ during fuel cell operation (where $\mathrm{H}_{2} \mathrm{O}$ is electrogenerated at the anode), a subsequent approach was developed where the imidazole group of the PBI chains is alkylated, which yielded positively charged alkylimidazolium groups in the PBI backbone. One of the first of such studies was published by Hu et al. who synthesized methylated PBI (mPBI) in 1993 [34]. The intention of this prior work was not the application of the new material in fuel cells but the fundamental investigation of the change of properties of the methylated PBI compared to pure PBI. With a focus on application in PEMFCs, Pu et al. investigated methylated and ethylated PBI [35, 36]. The usage of alkylated PBI for development of anion-exchange materials was first mentioned (independently) in 2011 by Henkensmeier et al. and Holdcroft et al. [37, 38]. The methylated PBI synthesized by these two research groups were different in chemical structure. Membranes made of pure mPBI are mechanically stable and extremely flexible. However it was found that casted mPBI films are not hydrolytically stable and broke into pieces after three weeks of storage in water at $60^{\circ} \mathrm{C}$. Holdcroft et al. developed ionically cross-linked blend membranes by mixing dimethylated PBI with unmodified (non-methylated) PBI. Using this method, it was possible to stabilize the membranes over 13 days in aqueous $\mathrm{KOH}(2 \mathrm{M})$ at $60^{\circ} \mathrm{C}$ [39]. Henkensmeier et al. attempted to stabilize the films using covalent cross-linking with $\alpha, \alpha^{\prime}$-dibromo-p-xylene. To achieve higher chemical stabilities, a more recent approach was to integrate bulky groups at neighboring sites to the methylated imidazolium functionalities (the intention is to hinder the attack of the dialkylimidazolium group by the nucleophilic $\mathrm{OH}^{-}$ions) $[39,40]$. Henkensmeier et al. reported that $\mathrm{mPBI}$ with ether bridges were stable at room temperature in aqueous $\mathrm{KOH}$ (1 M) for over five days; this is compared to mPBI without ether bridges, which degraded at room temperature in aqueous $\mathrm{KOH}(0.5 \mathrm{M})$ [40].

In this study, we present the synthesis and characterization of a methylated polybenzimidazole (designated $\mathrm{mPBIOO}$ ), which is synthesized from an ether-link-containing PBI (PBIOO) starting polymer. mPBIOO was used to develop a novel type of mechanically and chemically stable AEM for application in alkaline DMFCs. Studies to date have all methylated PBI precursors using the highly toxic alkylation agent methyl iodide [34-38]. In 
this study a more facile and "green chemistry" PBI alkylation method is presented, which involves the non-toxic alkylation reagent dimethylcarbonate along with DABCO as the alkylation catalyst (see Figure 1). This work follows the studies of Shieh et al. [41-43] in which low-molecular benzimidazoles were alkylated with the DMC/DABCO reaction system. Our study successfully transferred this reaction to high molecular weight PBI systems. After the synthesis of mPBIOO, this polymer was then used to synthesize novel blend-type AEMs via mixing with sulfinated polysulfone (PPSU-SO ${ }_{2} \mathrm{Li}$, previously developed in the Stuttgart group for use as a covalent cross-linking polymer for acidic PEM blend membranes [44, 45]), diiodobutane (DIB), and DABCO (the latter has also recently been used for the preparation of AEM based on brominated poly(phenylene oxide) (PPO), DABCO and DIB [27]). In the novel blend membranes, the use of PPSU-SO ${ }_{2} \mathrm{Li}$ leads to good mechanical properties and a macrohomogeneous morphology when the AEMs are formed via reaction with $\mathrm{mPBIOO}$, DABCO and diiodobutane (DIB). It is important to note that transparent and mechanically stable AEM were only obtained when all four components (mPBIOO, PPSU-SO $2 \mathrm{Li}$, DIB and DABCO) were mixed: the mixing of only three components yielded extremely brittle and morphologically macro-inhomogeneous membranes. Based on these observations, it is concluded that sulfinated-PPSU takes part in the cross-linking/quaternization reaction (preliminary work has shown that sulfinated-PPSU reacts with DIB with formation of covalent networks built up via sulfinate-S alkylation [46]). Figure 2 summarizes the possible reactions which can take place on mixing of $\mathrm{mPBIOO}, \mathrm{PPSU}_{-} \mathrm{SO}_{2} \mathrm{Li}, \mathrm{DIB}$, and DABCO.

The ion exchange capacities (IEC), ion conductivities, and methanol uptakes of the resulting novel covalently cross-linked AEMs were investigated. The alkaline stabilities of the AEMs were also evaluated since this is a critically important property related to the use of AEM in AEMFCs. The $\mathrm{OH}^{-}$ion is a strong nucleophile and can therefore degrade the (positively charged) anion-exchange (facile leaving) groups, which would result in a significant loss of conductivity [30]. This study also shows that the application of the AEMs in an alkaline DMFC yields good (beginning-of-life) performances.

\section{Experimental}

\subsection{Materials}


All chemicals were used as received without any further purification steps. PBIOO was supplied by Fumatech (GmbH). 1,4-diazabicyclo[2.2.2]octane (DABCO), diiodobutane (DIB), dimethyl carbonate (DMC), N,N-dimethylacetamide (DMAc), n-buthyllithium ( $n$ $\mathrm{BuLi}$ ) were purchased from Sigma-Aldrich. The gaseous $\mathrm{SO}_{2}$ was ordered from Gerling Holz \& Co Handels GmbH and PPSU was purchased from Solvay.

\section{Methylated PBIOO}

PBIOO (10.0 g, $24.0 \mathrm{mmol})$ was dissolved in $300 \mathrm{~cm}^{3}$ DMAc at $50^{\circ} \mathrm{C}$. DMC $(6.5 \mathrm{~g}, 72 \mathrm{mmol})$ and $\mathrm{DABCO}(0.3 \mathrm{~g}, 2.4 \mathrm{mmol})$ was then added to the resulting brown solution along with a further $50 \mathrm{~cm}^{3}$ of DMAc. The reaction solution was heated at $145^{\circ} \mathrm{C}$ for $96 \mathrm{~h}$. After cooling to room temperature, the solution was slowly poured into $2000 \mathrm{~cm}^{3}$ acetone. A brown polymer precipitate was obtained. The product was filtered and washed two times with acetone and then dried at $90^{\circ} \mathrm{C}$ for $24 \mathrm{~h}$. Yield: $9.8 \mathrm{~g}(23 \mathrm{mmol}$; 93\%). Degree of Methylation: $51 \%$ (based on two nitrogen per repeat unit; in other words: $51 \%$ monomethylation of PBIOO).

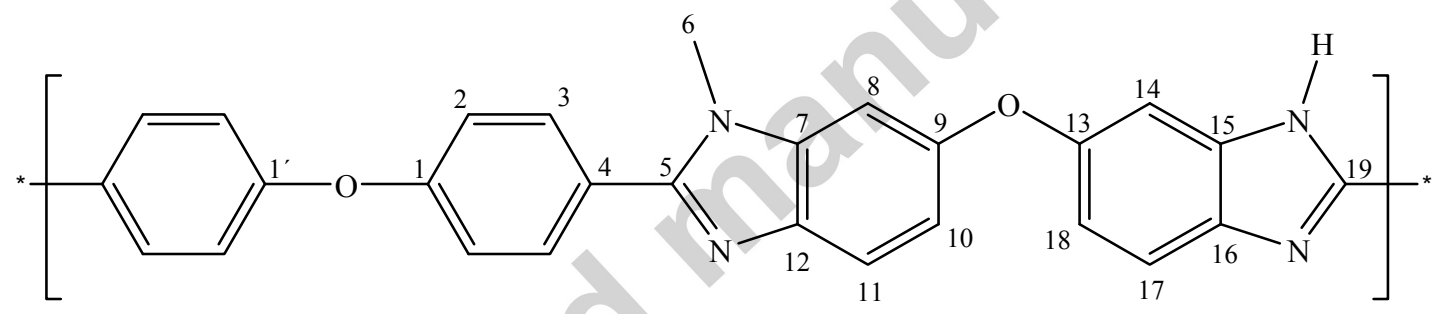

${ }^{1} \mathrm{H}-\mathrm{NMR}$ (400 MHz, DMSO+TFA, ppm): $\delta=8.03$ (d, $\left.J=8.4 \mathrm{~Hz}, \mathrm{H}-3,4.6 \mathrm{H}\right), 7.97$ (d, $J=8.8$ Hz, H-17, 1.1 H), 7.87 (d, J=8.8 Hz, H-11, 1 H), 7.66 (s, H-8, $1.1 \mathrm{H}), 7.46$ (s, H-14), 7.45 (d, $J=8.6 \mathrm{~Hz}, \mathrm{H}-2,5.6 \mathrm{H}(\mathrm{H}-14$ is also integrated)), 7.32 (d, $J=9.8 \mathrm{~Hz}, \mathrm{H}-18,1.1 \mathrm{H}), 7.24(\mathrm{~d}, J$ $=8.8 \mathrm{~Hz}, \mathrm{H}-10,1.1 \mathrm{H}), 4.04(\mathrm{~s}, \mathrm{H}-6,3.4 \mathrm{H}), 3.97$ (s, H-6, $2.9 \mathrm{H}) ;{ }^{13} \mathrm{C}-\mathrm{NMR}(100 \mathrm{MHz}$, DMSO+TFA, ppm): $\delta=159.23$ (C-19), 158.88 (C-1), 155.00 (C-13), 154.88 (C-9), 151.77 (C-5), 136.06 (C-15), 136.01 (C-7), 132.55 (C-3), 131.69 (C-12), 131.61 (C-16), 121.74 (C4), 119.75 (C-2), 117.78 (C-11), 117.06 (C-10), 116.98 (C-18), 113.94 (C-17), 105.80 (C-14), 102.51 (C-8), 32.86 (C-6), 32.83 (C-6).

\section{sPPSU Radel R}

The synthesis of monosulfinated polysulfone (PPSU) was described in earlier work [44]. Radel $\mathrm{R}^{\circledR}$ PPSU (20.0 g, $49.9 \mathrm{mmol}$ ) was dissolved in $1000 \mathrm{~cm}^{3}$ of anhydrous THF under an Ar atmosphere. $n$-Butyllithium ( $n$-BuLi) was slowly added after the resulting polymer solution was cooled down to $-65^{\circ} \mathrm{C}$ in a Dewar vessel. The $n$-BuLi (2.5 M in hexane) was 
initially added until a weak red/orange solution coloration was observed (indicates the beginning of the deprotonation of the polymer). $n$-BuLi (12.5 ml, $49.9 \mathrm{mmol}, 10 \mathrm{M})$ was then added for a stoichiometric reaction. After 90 min of stirring $\mathrm{SO}_{2}$ gas was introduced via a gas inlet. During this process, the solution changed from red/orange to pale yellow and after $5 \mathrm{~min}$ the sulfonation reaction was finished. The mixture was then warmed up to room temperature and slowly poured in $2000 \mathrm{~cm}^{3}$ iso-propanol. The resulting polymer precipitate was then filtered, washed several times with iso-propanol, and dried at $50^{\circ} \mathrm{C}$ under vacuum. Yield: 22.0 g (46.7 mmol; 93.6\%)

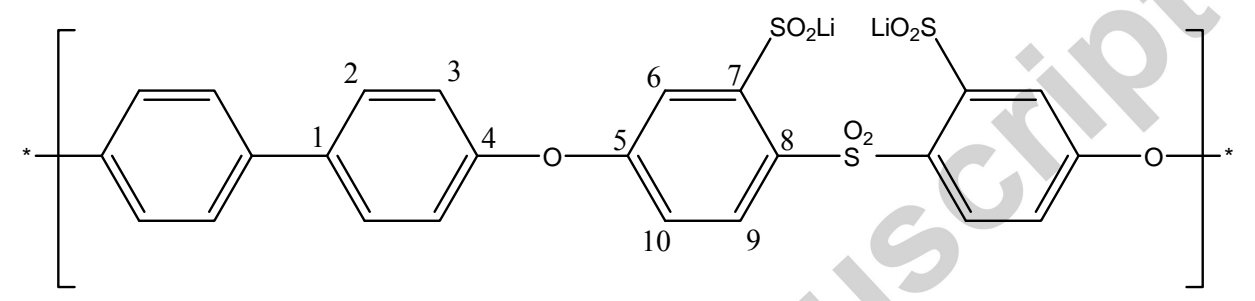

${ }^{1} \mathrm{H}-\mathrm{NMR}(250 \mathrm{MHz}, \mathrm{DMSO}, \mathrm{ppm}) \delta=8.02$ (d, H9); 7.74 (d, H2); 7.54 (d, H6); 7.17 (d, H3); 7.04 (d, H10); ${ }^{13} \mathrm{C}-\mathrm{NMR}$ (60 MHz, DMSO, ppm) $\delta=163.87$ (C5); 161.29 (C7); 154.62 (C4); 132.74 (C8); 135.61 (C1); 130.80 (C9); 128.36 (C2); 120.26 (C3); 116.94 (C10); 111.61 (C6).

\subsection{Membrane Preparation}

The membranes were composed of $70 \mathrm{wt} \% \mathrm{mPBIOO}, 30 \mathrm{wt} \% \mathrm{PPSU}_{-} \mathrm{SO}_{2} \mathrm{Li}$ and $\mathrm{DABCO}$ and DIB in the molar ratio of 1:1.17:1.17 for PPSU-SO ${ }_{2} \mathrm{Li}: D A B C O: D I B$. Example synthesis: mPBIOO (1.2248 g, $2.817 \mathrm{mmol})$, PPSU-SO $2 \mathrm{Li}$ (0.5281 g, $0.999 \mathrm{mmol})$, DABCO (0.1347 g, $1.172 \mathrm{mmol})$, and DIB (0.3664 g, $1.172 \mathrm{mmol})$ were mixed for preparation of a $24 \times 24 \mathrm{~cm}$ membrane with a target thickness of $26 \mu \mathrm{m}$. All of the components were pre-dissolved in DMAc (concentration 5\%). Before the PPSU-SO $\mathrm{S}_{2} \mathrm{Li}$ solution was added, the mPBIOO solution was filtered through a cotton fleece. To the mixed polymer solution DABCO and diiodobutane solutions were added. The solution was cast on a glass plate, and the film was formed in an oven at $140^{\circ} \mathrm{C}$ by solvent evaporation. To obtain the $\mathrm{OH}^{-}$form AEM (AAEM), all membranes were soaked in aqueous $\mathrm{KOH}(1 \mathrm{M})$ for $24 \mathrm{~h}$ at $50^{\circ} \mathrm{C}$ and washed several times at room temperature with millipore water $(18 \mathrm{M} \Omega)$. The films were stored in millipore water.

\subsection{Polymer and Membrane Characterization}




\subsubsection{Structure Analysis}

NMR spectra were collected on a Bruker Avance 400 spectrometer to characterize the structure and calculate how much hydrogen groups could be substituted by a methylgroup in mPBIOO and how much sulfinate groups could be integrated in PPSU.

\subsubsection{Molecular weight determination via Size exclusion chromatography (GPC)}

The molecular weight distribution (MWD) of PBIOO and mPBIOO was measured by gel permeation chromatography (GPC)/size exclusion chromatography (SEC), carried out with an Agilent Technologies GPC system (Series 1200) using a refractive index detector (Shodex RI71). The GPC system was calibrated with polystyrene. For the GPC analysis, $0.2 \mathrm{wt} \%$ solutions of the polymers in DMAc with $5 \mathrm{wt} \%$ Lithiumbromid $(\mathrm{LiBr})$ were prepared. The molar mass distribution was measured with a flowrate of $1 \mathrm{ml} / \mathrm{min}$ at $50{ }^{\circ} \mathrm{C}$.

\subsubsection{Cross-linking degree (solvent extraction)}

To determine the cross-linking degree (gel content) of the AEMs, an extraction process was applied. During this process, all components of the membrane that are not part of the polymer network were removed. The extraction process was performed by soaking the membrane samples in DMAc for $4 \mathrm{~d}$ at $80^{\circ} \mathrm{C}$ (changing the DMAc after $2 \mathrm{~d}$ to remove dissolved blend constituents), soaking in water for $2 \mathrm{~d}$ at $80^{\circ} \mathrm{C}$, and finally immersion in methanol at room temperature for $1 \mathrm{~d}$. The cross-linking degree was calculated using Equation 1.

$C D[\%]=\frac{W_{n}}{W_{b}} \times 100$

where $C D$ was the cross-linking degree/gel content, $w_{b}$ was the weight before extraction and $w_{a}$ was the weight after extraction.

\subsubsection{Ion Exchange Capacity (IEC)}

To measure the IEC (meq ${ }^{-1}$ ) of an AEM sample a back-titration method was used. The AEM $\left(\mathrm{OH}^{-}\right.$form) sample was immersed in saturated aqueous $\mathrm{NaCl}$ solution for $24 \mathrm{~h}$ (releasing the $\mathrm{OH}^{-}$anions into the solution). A defined amount of aqueous $\mathrm{HCl}(0.1 \mathrm{M})$ solution was then 
added to react with the $\mathrm{OH}^{-}$ions. The AEM sample was removed from the solution, rinsed with water, dried at $80^{\circ} \mathrm{C}$, and weighed. The amount of remaining $\mathrm{H}^{+}$ions in the solution were then determined by titration with aqueous $\mathrm{NaOH}(0.01 \mathrm{M})$ solution. Equation 2 was used to calculate the total IEC.

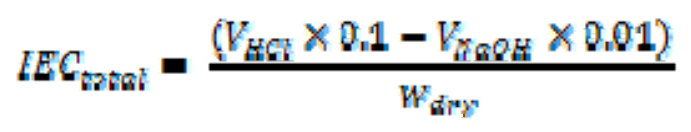

where $V_{\mathrm{HCl}}\left(\mathrm{dm}^{3}\right)$ was the defined volume of aqueous $\mathrm{HCl}(0.1 \mathrm{M})$ added, $V_{\mathrm{NaOH}}\left(\mathrm{dm}^{3}\right)$ was the titrant [aqueous $\mathrm{NaOH}(0.01 \mathrm{M})$ ] volume added, and $w_{d r y}$ was the weight of the dry membrane (predominantly $\mathrm{Cl}^{-}$form).

\subsubsection{Conductivity}

The specific resistances of the AEMs were determined via impedance spectroscopy using a Zahner elektrik IM6 impedance spectrometer. The resistance of each sample was measured in through-plane mode using a frequency range of $200 \mathrm{kHz}$ to $4 \mathrm{MHz}$ and a voltage perturbation amplitude of $5 \mathrm{mV}$. For each membrane, a first measurement was conducted with two membrane samples pressed together in aqueous $\mathrm{NaCl}(1 \mathrm{M})$ solution and a second with three membrane samples pressed together: the Nyquist plot was recorded for each and the resistance value from the first measurement was subtracted from the second measurement. The resistance of the membrane obtained using this method corrects for cell component resistances (such as the resistances between each electrode and the corresponding membrane surface). Equation 3 was used to calculate the ion conductivity of the membranes.

$$
\sigma=\frac{1}{r_{s p}}=\frac{d}{R \times A}
$$

where $\sigma$ was the ionic conductivity $\left(\mathrm{Cl}^{-}\right), r_{s p}$ is the resistivity, $d$ was the thickness of the hydrated membrane, $R$ was the determined ohmic resistance (cell ccorrected as detailed above), and $A$ was the area of the membrane samples.

\subsubsection{Methanol-water Uptake}


The methanol-water $(M U)$ uptakes of the extracted membrane samples were determined after equilibration for $24 \mathrm{~h}$ in aqueous methanol $(4 \mathrm{M})$ at defined temperatures. The weight of the "wet" and dry membranes was measured and the $M U$ was calculated using Equation 4:

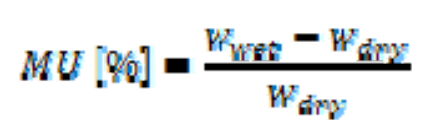

where $w_{\text {wet }}$ was the weight of the "wet" membrane and $w_{d r y}$ was weight of the dry membrane.

\subsubsection{Alkaline Stability}

Pieces of the AEM were aged in aqueous $\mathrm{KOH}(1 \mathrm{M})$ at $90^{\circ} \mathrm{C}$ for increasing time intervals. The solutions were cooled down to room temperature and the aged membranes were washed several times with bi-distilled water. After washing, the $I E C_{\text {total }}$ was measured for each aged sample (as described above) and the membranes were dried in the $\mathrm{Cl}^{-}$form. Subsequently the membrane samples were soaked in aqueous sodium chloride $(1 \mathrm{M})$ solution for impedance analysis and determination of conductivities.

\subsubsection{DMFC Beginning-of-Life Performances}

DMFC measurements were done in two different cells. The initial test bench from Varcoe et al. (at the University of Surrey) had an active area of $25 \mathrm{~cm}^{2}$ and a serpentine flow field. It was used to study the effect of the solvent extraction process. An anode fuel supply of aqueous $\mathrm{MeOH}(2 \mathrm{M})$ containing $\mathrm{KOH}(1 \mathrm{M})$ was used at a flow rate of $4 \mathrm{~cm}^{3} \mathrm{~min}^{-1}$ at $50^{\circ} \mathrm{C}$. With the spraying technique, previously described by Varcoe et al. [19, 47], Pt black as cathode $\left(2 \mathrm{mg} \mathrm{cm}^{-2}\right)$ and PtRu black $\left(4 \mathrm{mg} \mathrm{cm}^{-2}\right)$ as anode were coated onto the electrode surfaces. Humidified $\mathrm{O}_{2}$ at a flow rate of $200 \mathrm{~cm}^{3} \mathrm{~min}^{-1}$ (and a dew point $=45^{\circ} \mathrm{C}$ ) was used at the cathode. An Arbin fuel cell test station (FCTS) was used for the testing.

To optimize the DMFC performance of the membranes, and to reduce cost, the fuel cell lab of ZSW institute (Ulm) developed membrane electrode assemblies (MEA) with platinum-free electrodes. The anode consisted of a gas diffusion electrode (GDE) containing a supported $\mathrm{Pd}$ catalyst $\left(6 \% \mathrm{Pd} / \mathrm{CeO}_{2} / \mathrm{C}\right.$ which can be recalculated into $1 \mathrm{mg}$ metal loading $/ \mathrm{cm}^{2}$, product number: 3020, Acta). The cathode consisted of a GDE with a supported FeCo catalyst ( $4 \% \mathrm{FeCo} / \mathrm{C}$ which can be recalculated into $0.3 \mathrm{mg}$ metal loading $/ \mathrm{cm}^{2}$, product number: 4010 , 
Acta). This fuel cell had an active area of $1 \mathrm{~cm}^{2}$, a serpentine flow field and was operated at $80^{\circ} \mathrm{C}$. The fuel supply was aqueous $\mathrm{MeOH}(4 \mathrm{M})$ containing $\mathrm{KOH}(5 \mathrm{M})$ supplied at a flow rate of $4 \mathrm{~cm}^{3} \mathrm{~min}^{-1}$. A DMFC test bench with a gilded stainless steel cell was used. Pure oxygen was fed at the cathode side with a flow rate of $80 \mathrm{~cm}^{3} \mathrm{~min}^{-1}$. Before the voltage/current performance curves were collected, the MEA was rinsed inside the cell with the fuel electrolyte until a constant resistance was obtained.

\section{Results and Discussion}

\subsection{Synthesis of mPBIOO}

To introduce (cationic) anion-exchange groups not only onto the side chains but also into the backbone, a diether type polybenzimidazole (PBIOO) was chosen as the base polymer for modification. One of the nitrogen's of the imidazole groups was methylated (see Figure 1). Other research groups have used the strongly toxic methylation agent methyl iodide (MeI) for the alkylation of imidazole groups (to form anion-exchange groups) [34-38]. It was the intention of this study to substitute $\mathrm{MeI}$ with a non-toxic methylation reagent system. A procedure for the alkylation of low-molecular benzimidazoles [41-43] was found by Shieh et $a l$, which used a non-toxic methylation mixture composed of DMC along with DABCO as a catalyst. In the present study, we adapted the method of Shieh et al. to methylate high molecular weight engineering polymer PBIOO for the first time. Figure 3 presents the ${ }^{1} \mathrm{H}$ NMR spectra of mPBIOO. Two sharp singlets at $\delta=4.0 \mathrm{ppm}$ were observed and these were assigned to the methyl groups of mPBIOO. In this study, the methylation degree of the mPBIOO was of $51 \%$ (calculated from the NMR data).

In Table 1 and Figure 4 shows the molecular mass of PBIOO and mPBIOO measured by GPC. The number average molecular weight of $\mathrm{mPBIOO}$ decreased in comparison with the educt PBIOO, while the weight average molecular weight increases. The increase of the PDI can be explained by the formation of high molecular weight polymer. Figure 4 depicted the molecular weight distribution. It can be seen that the intensity of the mPBIOO signal decreases compared to the PBIOO signal. Moreover the mPBIOO signal becomes broader because of the higher share of the high molecular weight.

\subsection{Membrane preparation and cross-linking degree}


During the evaporation of the solvent from the blend cast solution, the parallel formation of covalent cross-linking and quaternary ammonium groups was anticipated (Figure 2). All membranes were mechanically strong, optically transparent, and flexible. The developed AEMs consisted of four components making the determination of the component(s) present in the highest concentration in the covalent network difficult (especially as the control experiments with 3-component-only membranes [mPBIOO/DIB/DABCO, PPSU$\mathrm{SO}_{2} \mathrm{Li} / \mathrm{DIB} / \mathrm{DABCO}, \mathrm{mPBIOO} / \mathrm{PPSU}-\mathrm{SO}_{2} \mathrm{Li} / \mathrm{DIB}$, or mPBIOO/PPSU-SO $\left.{ }_{2} \mathrm{Li} / \mathrm{DABCO}\right] \mathrm{did}$ not yield homogeneous, transparent and mechanically stable films, despite the facts that 1) from reaction of DABCO with DIB, linear, water-soluble polyelectrolytes are obtained, 2) reaction of PPSU-SO $\mathrm{S}_{2} \mathrm{Li}$ with DIB and 3) reaction of $\mathrm{mPBIOO}$ with DIB both yield crosslinked polymer networks). In the 4-component blend it is impossible to distinguish between the different kinds of reactions taking place within it since the different reactions may take place in different extent in the 4-component blend, compared to the 2- or 3-component blends. Moreover, it was also not possible to obtain homogeneous and transparent membranes using alternative mass ratios of the blend components (rather than those mentioned in the experimental section). Hence, to obtain AEMs with different degrees of cross-linking, the solvent evaporation temperature used during membrane formation was varied.

Table 2 shows the effect of the evaporation temperatures on the cross-linking degrees/gel contents and the IECs of the resultant AEMs. The covalent cross-linking reactions (depicted in Figure 2) did not commence until a solvent evaporation temperature of $100^{\circ} \mathrm{C}$ was used: increased levels of cross-linking were obtained with further increases in temperatures. The obtained IEC values were high $\left(>2.4 \mathrm{meq} \mathrm{g}^{-1}\right)$ and the cross-linked AEMs had good mechanical stabilities that retain integrity during solvent extraction process (applied to remove soluble constituents from the 4-component blend membranes). In the following discussions, the samples are designated by their cross-linking degree.

\subsection{Ion Exchange Capacity and Conductivities}

Table 3 lists the $\mathrm{IEC}_{\text {total }}$ values and the $\mathrm{Cl}^{-}$conductivities before and after the extraction procedure. The differences between the IECs before and after extraction process decreases with increasing degree of cross-linking. This indicates that AEMs samples with lower crosslinking degrees lose quaternary ammonium contents during the extraction process, in contrast to the AEMs containing higher levels of cross-linking. The trend with the chloride 
conductivity values was less clear cut (within experimental errors), but generally no significant decrease or increase in values were observed.

\subsection{Methanol Uptake}

Since the intention is to use the novel AEMs in alkaline direct methanol fuel cells, the methanol/water uptake behavior of the membrane was tested using an aqueous methanol (4 M) solution [similar to that used in the alkaline DMFCs]. Figure 5 depicts the MU values at different temperatures of AEMs with different degrees of cross-linking. As expected, the methanol uptakes generally decreased with increasing cross-linking degree. Hence the use of more cross-linked AEMs of this type will be beneficial for application in alkaline DMFCs (reduced methanol crossover). Cross-linking degree was observed to be more critical that temperature: only small increases in MU were observed when the temperature was raised.

\subsection{Assessment of Alkaline Stability}

AEMs which are to be used in DMFCs that are fed with $\mathrm{KOH}$ contents in the aqueous methanol anode fuel supply must be stable to high $\mathrm{pH}$ environments. Degradation of AEMs in alkaline form (in alkaline media) is typically ex situ assessed by a decrease in ion conductivity or IEC with ageing time (submerged in alkaline aqueous solutions): the loss of IEC and conductivity stems from the loss of anion-exchange groups via the numerous degradation reactions as described in a review by Varcoe et al. [48]. All membrane types in the presented study showed reasonable alkaline stabilities over $10 \mathrm{~d}$ ageing times (within experimental errors). Figures 6 and 7 show the dependence of the IEC values and ion conductivities with AEM sample immersion time. The IEC values decreased to no less than $78 \%$ of the initial values after $10 \mathrm{~d}$ (with the harsh degradation temperature of $90^{\circ} \mathrm{C}$ ): no general trend in degradation levels and degree of cross-linking degree could be elucidated. The degradation in IECs was less apparent before $7 \mathrm{~d}$ ageing time. The $\mathrm{Cl}^{-}$conductivity of the AEM with $56 \%$ cross-linking initially showed an increase in conductivity on ageing time with a recovery of the initial conductivity level at $10 \mathrm{~d}$ ageing. We hypothesize that the initial rise in conductivity was due to the degradation of non-ionic components of the blend membrane during the immersion in aqueous $\mathrm{KOH}$ solution. The loss of non-ionic components can lead to an enlargement of the ionic transport channels, which leads to higher ion conductivities. Again, the degradation appears to accelerate after ageing time of $>7 \mathrm{~d}$. The mechanical 
stabilities of the cross-linked AEMs remained constant with ageing. In other published work from our group (different polymer systems made of brominated poly(2,6-dimethyl-1,2phenylenoxide), the IEC values and conductivities were very stable but the materials started to get brittle on ageing in aqueous alkali [27].

Additionally to this series of experiments, a membrane sample with gel content of $68 \%$ was further immersed for $59 \mathrm{~d}$ in aqueous $\mathrm{KOH}(1 \mathrm{M})$ at $90^{\circ} \mathrm{C}$. The film was still mechanical stable after this longer-term ageing process and an experimental IEC value of 2.3 meq $\mathrm{g}^{-1}$ and an ion conductivity of $1.4 \mathrm{mS} \mathrm{cm}^{-1}$ was obtained. This indicates an excellent stability to aqueous alkali for this AEM. Holdcroft et al. also presented a blend membrane which is stable under alkaline conditions (room temperature, aqueous $\mathrm{KOH}(6 \mathrm{M}), 3$ month), but the IEC value was initially lower $\left(1.5 \mathrm{meq}^{-1}\right)$ than for the AEMs presented in this study. Holdcroft et al.'s membrane also had a high water uptake (119\%) [39, 49]. A lower water uptake leads to less swelling and therefore to a better in situ mechanical stability when applied in fuel cells.

\subsection{DMFC application}

The first DMFC measurements were made in a fuel cell with an active area of $25 \mathrm{~cm}^{2}$ with a cell temperature of $50^{\circ} \mathrm{C}$ (Figure 8). The beginning-of-life $V / I$ curves (and associated power density) of a 4-compound-membrane before and after extraction are compared. In this specific case the covalent cross-linking degree/gel content was $45 \%$ (IEC $=2.4 \mathrm{meq} \mathrm{g}^{-1}$ after extraction). A significant performance increase was detected for the extracted membrane. This improvement was not foreseen as there was no significant difference between the ion conductivity measured before and after the extraction procedure $\left(2.5\right.$ and $2.4 \mathrm{mS} \mathrm{cm} \mathrm{cm}^{-1}$ respectively). The removal of non-covalently bound components in the membrane is the probable cause of this strong increase in fuel cell performance. A peak power density of 5.1 $\mathrm{mW} \mathrm{cm}{ }^{-2}$ was obtained for the extracted membrane in contrast to the non-extracted membrane $\left(1.4 \mathrm{~mW} \mathrm{~cm}^{-2}\right)$. Therefore, the extraction of this specific AEM led to an improvement in power density by a factor of three.

Figure 9 presents the DMFC performance of a 4-compound-membrane which was operated in an optimized fuel cell configuration with a non-Pt-containing MEA. This alkaline DMFC was operated at a higher temperature of $80^{\circ} \mathrm{C}$ and with higher fuel component concentrations. With the change of these parameters, the maximum power density reached almost $120 \mathrm{~mW} \mathrm{~cm}^{-2}$, which is among the best results obtained for an AEM-based DMFC. In 
our previous study, dealing with quaternized brominated-PPO membranes (BrPPO), a peak power output of $132 \mathrm{~mW} \mathrm{~cm}^{-2}$ was achieved under the same conditions and with the same catalysts [27]. However, the BrPPO AEMs were not as stable under alkaline conditions compared to the novel 4-component AEMs presented in this work.

\section{Conclusion}

We developed a facile method for methylation of high molecular weight ether-containing PBI (PBIOO) that avoided the use of carcinogenic reagents. The newly developed metylated PBIOO (mPBIOO) based anion-exchange membranes (AEM) exhibited good mechanical and alkaline stabilities. The AEMs were built up by mixing the four components 1,4diazabicyclo[2.2.2] octane (DABCO), mPBIOO, sulfinated polysulfone (PPSU-SO ${ }_{2} \mathrm{Li}$ ), and diiodobutane (DIB) which yielded homogeneous and transparent AEMs. The cross-linking degree (insoluble content) of the AEMs could be controlled by using different temperatures for solvent evaporation during the AEM casting (formation) process. The properties of the AEMs were investigated before and after the solvent extraction process that was used to remove soluble (uncross-linked) components. For AEMs that had a lower degree of crosslinking, a loss of ion-exchange capacity (IEC) was observed during the extraction process. For higher cross-linked samples, the IEC values (and ionic conductivities) were unaffected by the extraction process. All IECs (after extraction) for the cross-linked AEMs were $2.3 \pm 0.1$ meq $\mathrm{g}^{-1}$. The alkaline stability of the 4-component membrane was also tested. There was no significant decrease in IEC, the conductivity or, mechanical stability when the AEMs were aged in aqueous $\mathrm{KOH}(1 \mathrm{M})$ for up to $7 \mathrm{~d}$. An exemplar AEM was similarly aged for $59 \mathrm{~d}$ : after this time, the AEM properties remained stable.

Samples of select AEMs were tested in alkaline DMFC set-ups. The DMFC performance increased using an AEM that have been treated with the solvent extraction procedure. An alkaline AEM-MEA was fabricated using non-Pt Acta catalysts. This MEA yielded a maximum power density of $120 \mathrm{~mW} \mathrm{~cm}^{-2}$ in a AEM-DMFC (one of the highest values obtained to date for an AEM-DMFC containing non-Pt catalysts).

Further improvement of the DMFC performance could be achieved by optimizing the catalysts or the operating parameters. This will be done in future work. Furthermore membranes with other diamines like TMHDA instead of DABCO will be tested to compare the alkaline stabilities and the DMFC performance. Continuing work will be also done for the 
optimization of the methylation reaction to decreases the reaction time and to increase the substitution degree.

\section{Acknowledgment}

The authors would like to thank the AiF- Bundesministerium für Wirtschaft und Technologie for the financial support, project No.16200N. The authors thank Inna Kharitonova and Galina Schumski for carrying out the polymer and membrane characterization. The University of Surrey's fuel cell test equipment is supported by EPSRC Grants EP/I004882/1 and $\mathrm{EP} / \mathrm{H} 025340 / 1$.

\section{References}

[1] X. Tongwen, F.F. Zha, Fundamental studies on a new series of anion exchange membranes: effect of simultaneous amination-cross-linking processes on membranes ionexchange capacity and dimensional stability, J. Membr. Sci. 199 (2002) 203-210.

[2] J.H. Hao, C. Chen, L. Li, L. Yu, W. Jiang, Preparation of solvent-resistant anion-exchange membranes, Desalination 129 (2000) 15-22.

[3] W. Lee, K. Saito, S. Furusaki, T. Sugo, K. Makuuchi, Design of urea-permeable anionexchange membrane by radiation-induced graft polymerization, J. Membr. Sci. 81 (1993) 295 305 .

[4] M.R. Hibbs, M.A. Hickner, T.M. Alam, S.K. McIntyre, C.H. Fujimoto, C.J. Cornelius, Transport Properties of Hydroxide and Proton Conducting Membranes, Chem. Mater. 20 (2008) 2566-2573.

[5] E. Yu, U. Krewer, K. Scott, Principles and Materials Aspects of Direct Alkaline Alcohol Fuel Cells, Energies 3 (2010) 1499-1528.

[6] F.R. Brushett, M.S. Thorum, N.S. Lioutas, M.S. Naughton, C. Tornow, H. Jhong, A.A. Gewirth, P.J.A. Kenis, A Carbon-Supported Copper Complex of 3,5-Diamino-1,2,4-triazole 
as a Cathode Catalyst for Alkaline Fuel Cell Applications, J. Am. Chem. Soc. 132 (2010) 12185-12187.

[7] M. Schulze, E. Gülzow, Degradation of nickel anodes in alkaline fuel cells, J. Power Sources 127 (2004) 252-263.

[8] C. Coutanceau, L. Demarconnay, C. Lamy, J.-M. Léger, Development of electrocatalysts for solid alkaline fuel cell (SAFC), J. Power Sources 156 (2006) 14-19.

[9] J.S. Spendelow, A. Wieckowski, Electrocatalysis of oxygen reduction and small alcohol oxidation in alkaline media, Phys. Chem. Chem. Phys. 9 (2007) 2654-2675.

[10] L.A. Adams, S.D. Poynton, C. Tamain, R.C.T. Slade, J.R. Varcoe, A Carbon Dioxide Tolerant Aqueous-Electrolyte-Free Anion-Exchange Membrane Alkaline Fuel Cell, ChemSusChem 1 (2008) 79-81.

[11] M.S. Naughton, F.R. Brushett, P.J.A. Kenis, Carbonate resilience of flowing electrolytebased alkaline fuel cells, J. Power Sources 196 (2011) 1762-1768.

[12] A. Verma, S. Basu, Direct use of alcohols and sodium borohydride as fuel in an alkaline fuel cell, J. Power Sources 145 (2005) 282-285.

[13] A. Tewari, V. Sambhy, M.U. Macdonald, A. Sen, Quantification of carbon dioxide poisoning in air breathing alkaline fuel cells, J. Power Sources 153 (2006) 1-10.

[14] A.G. Thomas, Specific conductance as an indicator of total dissolved solids in cold dilute waters, Hydrological Sciences 31 (1986) 81-92.

[15] L. Lebrun, N. Follain, M. Metayer, Elaboration of a new anion-exchange membrane with semi-interpenetrating polymer networks and characterisation, Electrochim. Acta 50 (2004) 985-993. 
[16] E.N. Komkova, D.F. Stamatialis, H. Strathmann, M. Wessling, Anion-exchange membranes containing diamines: preparation and stability in alkaline solution, J. Membr. Sci. 244 (2004) 25-34.

[17] M.R. Hibbs, M.A. Hickner, T.M. Alam, S.K. McIntyre, C.H. Fujimoto, C.J. Cornelius, Transport Properties of Hydroxide and Proton Conducting Membranes, Chem. Mater. 20 (2008) 2566-2573.

[18] J.R. Varcoe, R.C.T. Slade, E.L.H. Yee, S.D. Poynton, D.J. Driscoll, D.C. Apperley, Poly(ethylene-co-tetrafluoroethylene)-Derived Radiation-Grafted Anion-Exchange Membrane with Properties Specifically Tailored for Application in Metal-Cation-Free Alkaline Polymer Electrolyte Fuel Cells, Chem. Mater. 19 (2007) 2686-2693.

[19] J.R. Varcoe, R.C.T. Slade, E.L.H. Yee, An alkaline polymer electrochemical interface: a breakthrough in application of alkaline anion-exchange membranes in fuel cells, Chem. Commun. (2006) 1428-1429.

[20] D. Stoica, F. Alloin, S. Marais, D. Langevin, C. Chappey, P. Judeinstein, Polyepichlorhydrin Membranes for Alkaline Fuel Cells: Sorption and Conduction Properties, J. Phys. Chem. B 112 (2008) 12338-12346.

[21] B. Tang, P. Wu, H.W. Siesler, In Situ Study of Diffusion and Interaction of Water and Mono- or Divalent Anions in a Positively Charged Membrane Using Two-Dimensional Correlation FT-IR/Attenuated Total Reflection Spectroscopy, J. Phys. Chem. B 112 (2008) 2880-2887.

[22] Y. Wu, C. Wu, T. Xu, Y. Fu, Novel anion-exchange organic-inorganic hybrid membranes prepared through sol-gel reaction of multi-alkoxy precursors, J. Membr. Sci. 329 (2009) 236-245.

[23] J. Zhou, M. Unlu, J.A. Vega, P.A. Kohl, Anionic polysulfone ionomers and membranes containing fluorenyl groups for anionic fuel cells, J. Power Sources 190 (2009) 285-292. 
[24] G. Hwang, H. Ohya, Preparation of anion-exchange membrane based on block copolymers Part 1. Amination of the chloromethylated copolymers, J. Membr. Sci. 140 (1998) 195-203.

[25] G. Merle, M. Wessling, K. Nijmeijer, Anion exchange membranes for alkaline fuel cells: A review, J. Membr. Sci. 377 (2011) 1-35.

[26] E.N. Komkova, D.F. Stamatialis, H. Strathmann, M. Wessling, Anion-exchange membranes containing diamines: preparation and stability in alkaline solution, J. Membr. Sci. 244 (2004) 25-34.

[27] A. Katzfuß, V. Gogel, L. Jörissen, J. Kerres, The application of covalently cross-linked BrPPO as AEM in alkaline DMFC, J. Membr. Sci. 425-426 (2012) 131-140.

[28] B. Bauer, H. Strathmann, F. Effenberger, Desalination 79 (1990) 125-144.

[29] J. B. Edson, C. S. Macomber, B. S. Pivovar, J. M. Boncella, Hydroxide based decomposition pathways of alkyltrimethylammonium cations, J. Membr. Sci. 399- 400 (2012) 49- 59 .

[30] S. Chempath, B. R. Einsla, L. R. Pratt, C. S. Macomber, J. M. Boncella, J. A. Rau, B. S. Pivovar, Mechanism of Tetraalkylammonium Headgroup Degradation in Alkaline Fuel Cell Membranes, J. Phys. Chem. C, Vol. 112, No. 9, 2008, 3179-3182.

[31] B. Xing, O. Savadogo, Hydrogenroxygen polymer electrolyte membrane fuel cells (PEMFCs) based on alkaline-doped polybenzimidazole (PBI), Electrochem. Commun. 2 (2000) 697-702.

[32] H. Hou, G. Sun, R. He, B. Sun, Alkali doped polybenzimidazole membrane for alkaline direct methanol fuel cell, Int. J. Hydrogen Energy 22 (2008) 7172-7176.

[33] H. Hou, G. Sun, R. He, Z. Wu, B. Sun, Alkali doped polybenzimidazole membrane for high performance alkaline direct ethanol fuel cell J. Power Sources 182 (2008) 95-99. 
[34] M. Hu, E. M. Pearce, T. K. Kwei, Modification of Polybenzimidazole: Synthesis and Thermal Stability of Poly( N,-Methylbenzimidazole) and Poly ( N, ,N,Dimethylbenzimidazolium) Salt, J. Polym. Sci.: Part A Polym. Chem. 31 (1993) 553-561.

[35] H. Pu, G. Liu, Synthesis and solubility of poly(N-methylbenzimidazole) and poly(Nethylbenzimidazole): control of degree of alkylation, Polym. Int. 54 (2005) 175-179.

[36] H. Pu, G. Liu, Preparation and proton conductivity of poly(N-methylbenzimidazole doped with acid, Polym. Adv. Technol. 15 (2004) 726-730.

[37] O. D. Thomas, K. J. W. Y. Soo, T. J. Peckham, M. P. Kulkarni, S. Holdcroft, Anion conducting poly(dialkyl benzimidazolium) salts, Polym. Chem. 2 (2011) 1641-1643.

[38] D. Henkensmeier, H. Kim, H. Lee, D. H. Lee, I. Oh, S. Hong, S. Nam, T. Lim, Polybenzimidazolium-Based Solid Electrolytes, Macromol. Mater. Eng. 296 (2011) 899-908.

[39] O. D. Thomas, K. J. W. Y. Soo, T. J. Peckham, M. P. Kulkarni, S. Holdcroft, A Stable Hydroxide-Conducting Polymer, J. Am. Chem. Soc. 134 (2012) 10753-10756.

[40] D. Henkensmeier, H. Cho, H. Kim, C. Kirchner, J. Leppin, A. Dyck, J. H. Jang, E. Cho, S. Nam, T. Lim, Polybenzimidazolium hydroxides - Structure, stability and degradation, Polym. Degradation and Stability 97 (2012) 264-272.

[41] W. Shieh, S. Dell, O. Repic, 1,8-Diazabicyclo[5.4.0]undec-7-ene (DBU) and Microwave-Accelerated Green Chemistry in Methylation of Phenols, Indoles, and benzimidazoles with Dimethyl Carbonate, Org. Lett. 3(26) (2001) 4279-4281.

[42] W. Shieh, M. Lozanov, M. Loo, O. Repic, T.J. Blacklock, DABCO- and DBUaccelerated green chemistry for N-, O-, and S-benzylation with dibenzyl carbonate, Tetrahedron Lett. 44 (2003) 4563-4565.

[43] W. Shieh, S. Dell, A. Bach, O. Repic, T.J. Blacklock, Dual Nucleophilic Catalysis with DABCO for the N-Methylation of Indoles, J. Org. Chem. 68 (2003) 232-239. 
[44] J. Kerres, W. Cui, S. Reichle, New Sulfonated Engineering Polymers via the Metalation Route. 1. Sulfonated Poly(ethersu1fone) PSU UdeP via Metalation-Sulfination-Oxidation, $J$. Polym. Sci.: Part A: Polym. Chem. 34 (1996) 2421-2438.

[45] J. Kerres, Development of ionomer membranes for fuel cells, J. Membr. Sci. 185 (2001) $3-27$.

[46] J. Kerres, T. Häring, Oligomers and Polymers Containing Sulfonite Groups and Method for the Production thereof, PCT WO 03/022892 A2.

[47] Z. Zhang, L. Wu, J. Varcoe, C. Li, A. L. Ong, S. Poynton, T. Xu, Aromatic polyelectrolytes via polyacylation of pre-quaternized monomers for alkaline fuel cells, $J$. Mater. Chem. A 1 (2013) 2595-2601.

[48] J. R. Varcoe, R. C. T. Slade, Prospects for Alkaline Anion-Exchange Membranes in Low Temperature Fuel Cells, Fuel Cells 5(2) (2005) 187-200.

[49] O. Thomas, A. Wright, M. P. Kulkarni, T. Peckham, K. Soo, S. Holdcroft, HydroxideConducting Polybenzimidazolium salts, Workshop on Anion-Exchange Membranes for Energy Generation Technologies 2013, University of Surrey.

\section{Figure legends:}

Figure 1: Methylation of PBIOO forming mPBIOO.

Figure 2a: Reaction of a PPSU-SO $\mathrm{S}_{2} \mathrm{Li}$ repeat unit with DIB and/or DABCO.

Figure 2b: Reaction of a mPBIOO repeat unit with DIB and/or DABCO.

Figure 2c: Reaction of a mPBIOO repeat unit with DIB and a PPSU-SO $\mathrm{SL}_{2}$ Li repeat unit.

Figure 3: $\quad{ }^{1} \mathrm{H}-\mathrm{NMR}$ spectra of $\mathrm{mPBIOO}$ in d6-DMSO and d-TFA. 
Figure 4: $\quad$ Molar mass distribution of $\mathrm{PBIOO}$ and $\mathrm{mPBIOO}$

Figure 5: Methanol uptake of AEM samples with different cross-linking degree at different temperatures. The legend gives the degrees of cross-linking.

Figure 6: The IEC values after different AEM immersion times in aqueous KOH (1 M) at $90^{\circ} \mathrm{C}$. The legend gives the degrees of cross-linking.

Figure 7: The ion conductivity values after different AEM immersion times in aqueous $\mathrm{KOH}(1 \mathrm{M})$ at $90^{\circ} \mathrm{C}$. The legend gives the degrees of cross-linking.

Figure 8: Cell performance at $T_{\text {cell }}=50^{\circ} \mathrm{C}$ for a MEA with a $45 \%$ covalent cross-linked membrane before (b) and after (a) solvent extraction.

Figure 9: Cell performance at $T_{\text {cell }}=80^{\circ} \mathrm{C}$ for a MEA with a $37 \%$ covalent cross-linked AEM. Anode catalyst $=3020$ (Acta), cathode catalyst $=4010($ Acta $)$, oxidant $=$ dry oxygen, $A_{\text {cell }}=1 \mathrm{~cm}^{2}$, fuel supply = aqueous $\mathrm{MeOH}(4 \mathrm{M})+\mathrm{KOH}(5 \mathrm{M})$.

\section{Figures}
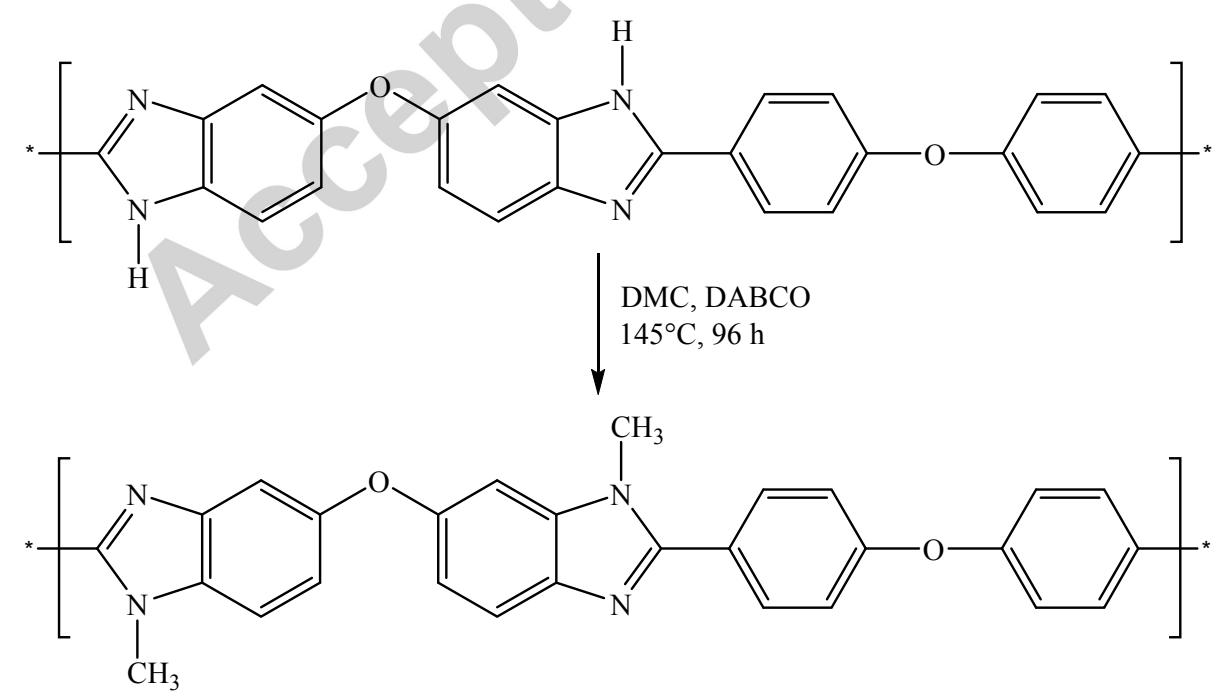

Figure 1: Methylation of PBIOO forming mPBIOO 


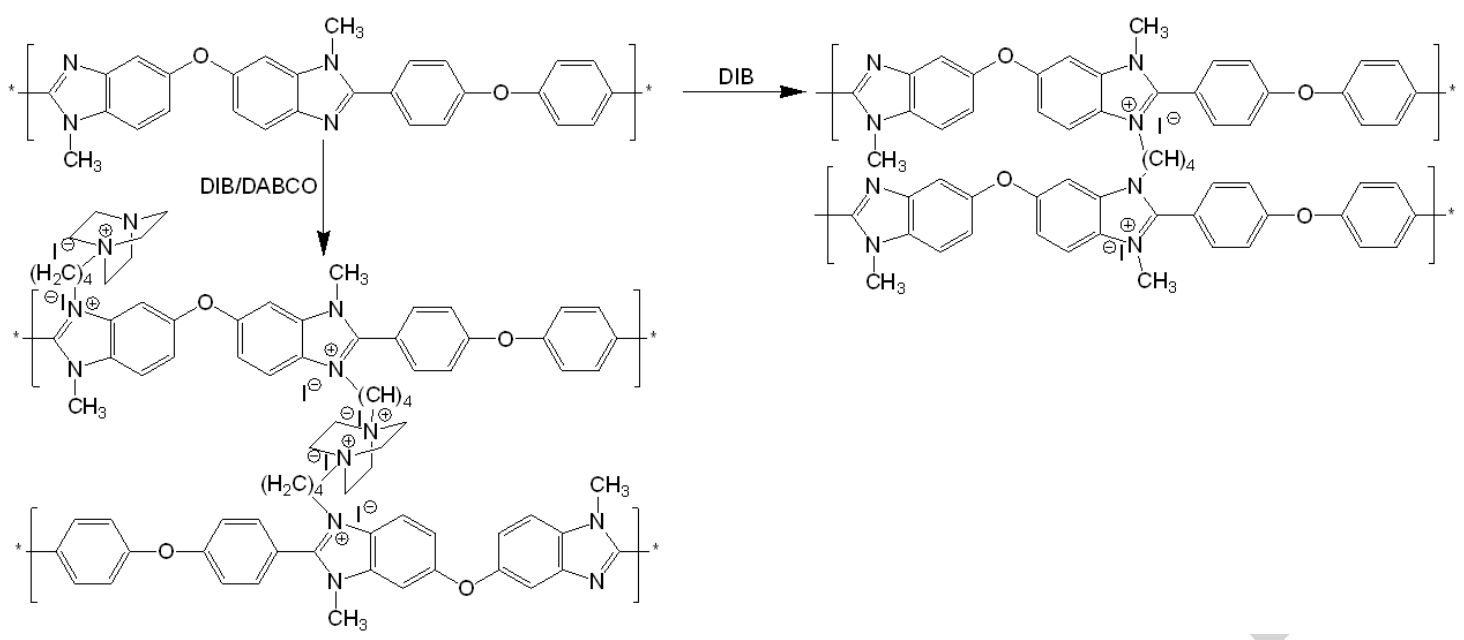

Figure 2a: Reaction of a PPSU-SO ${ }_{2} \mathrm{Li}$ repeat unit with DIB and/or DABCO
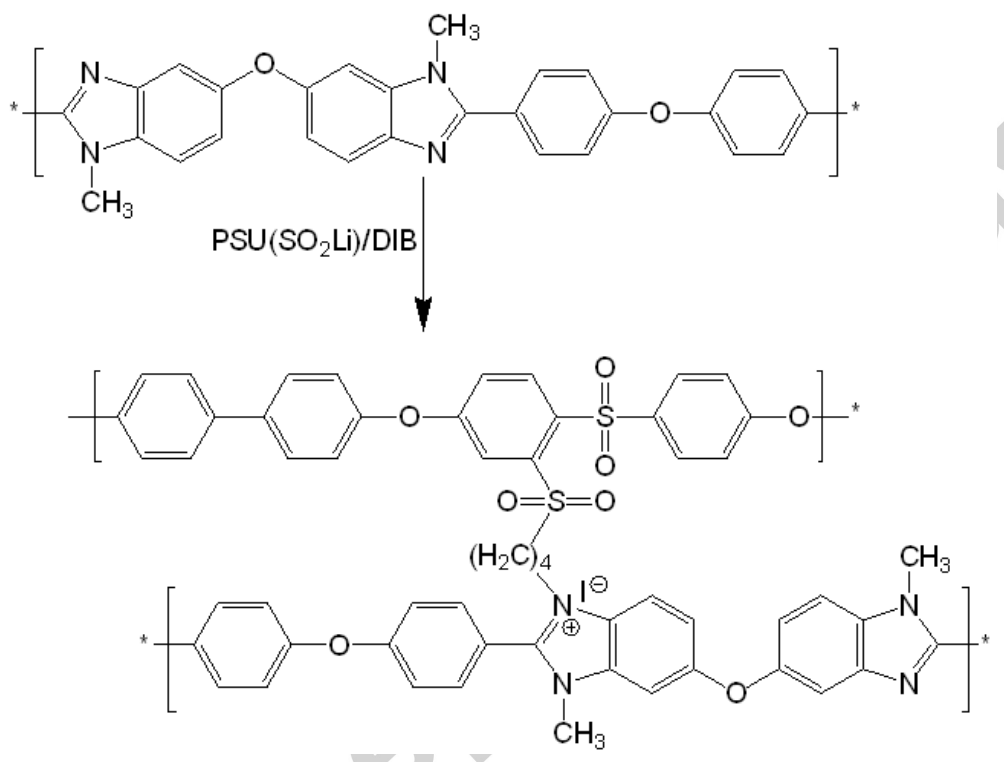

Figure 2b: Reaction of a mPBIOO repeat unit with DIB and/or DABCO 


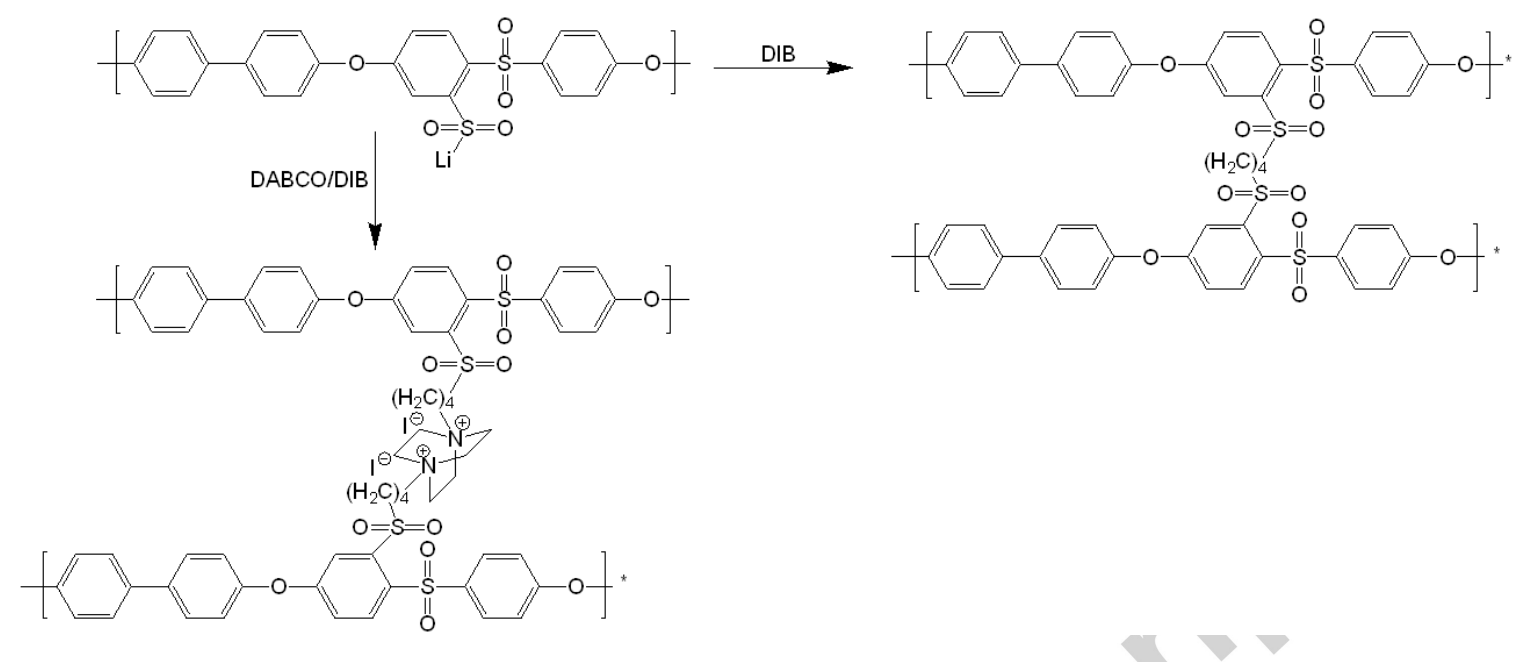

Figure 2c: Reaction of an mPBIOO repeat unit with DIB and a PPSU-SO ${ }_{2} \mathrm{Li}$ repeat unit 

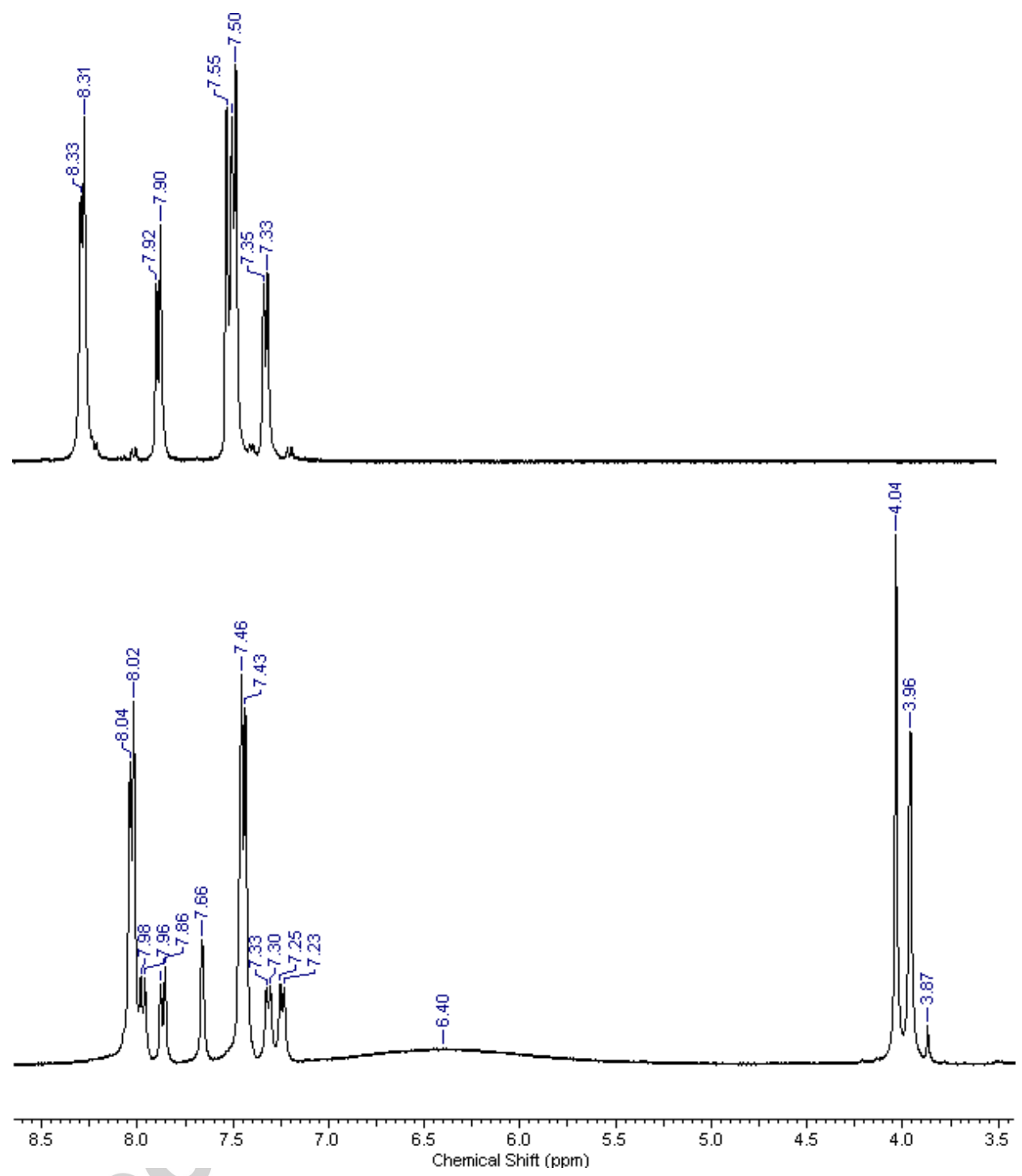

Figure 3: ${ }^{1}$ H-NMR spectra of PBIOO and mPBIOO in d6-DMSO and d-TFA 


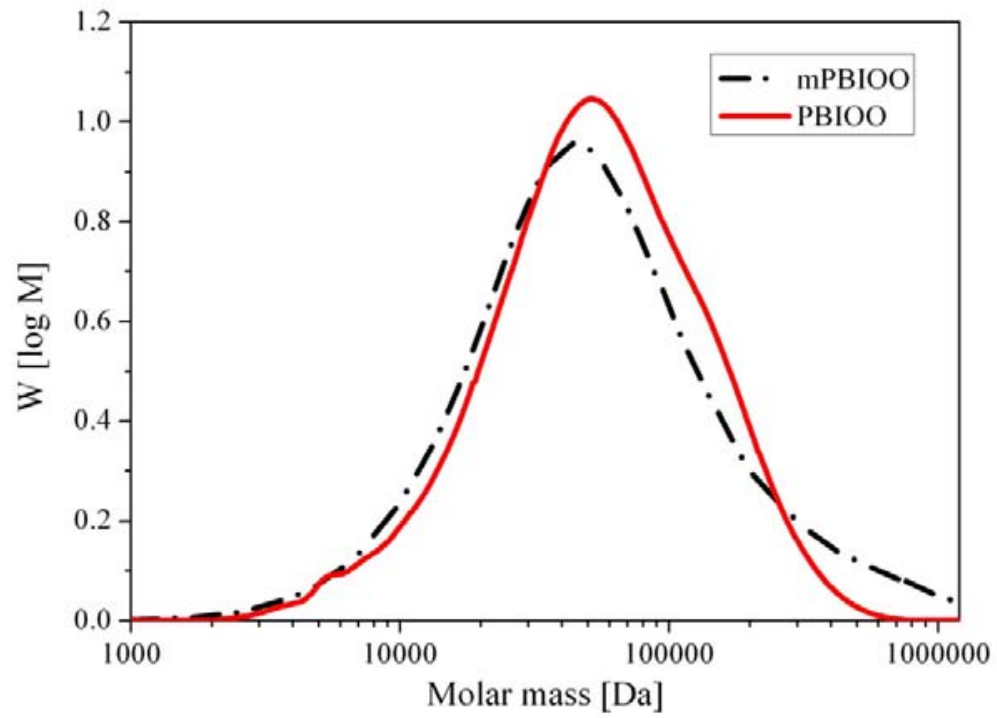

Figure 4: Molar mass distribution of $\mathrm{PBIOO}$ and $\mathrm{mPBIOO}$ 


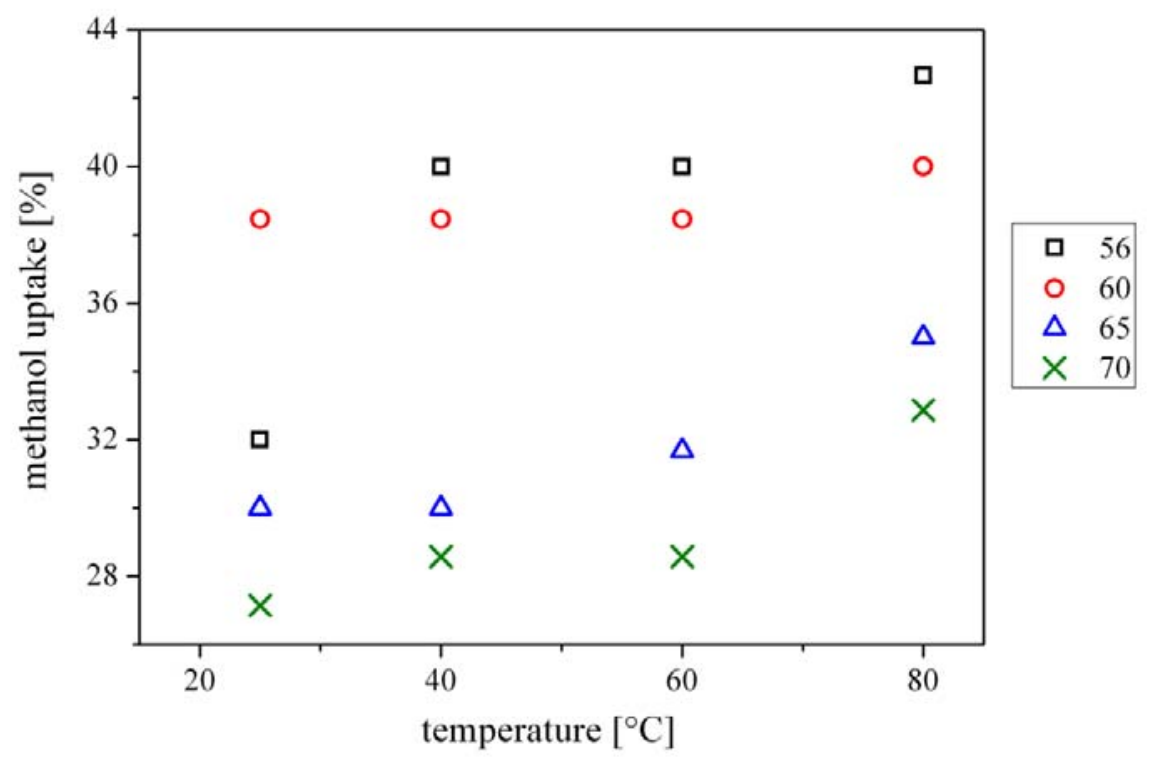

Figure 5: Methanol uptake of AEM samples with different cross-linking degree at different temperatures. The legend gives the degrees of cross-linking.

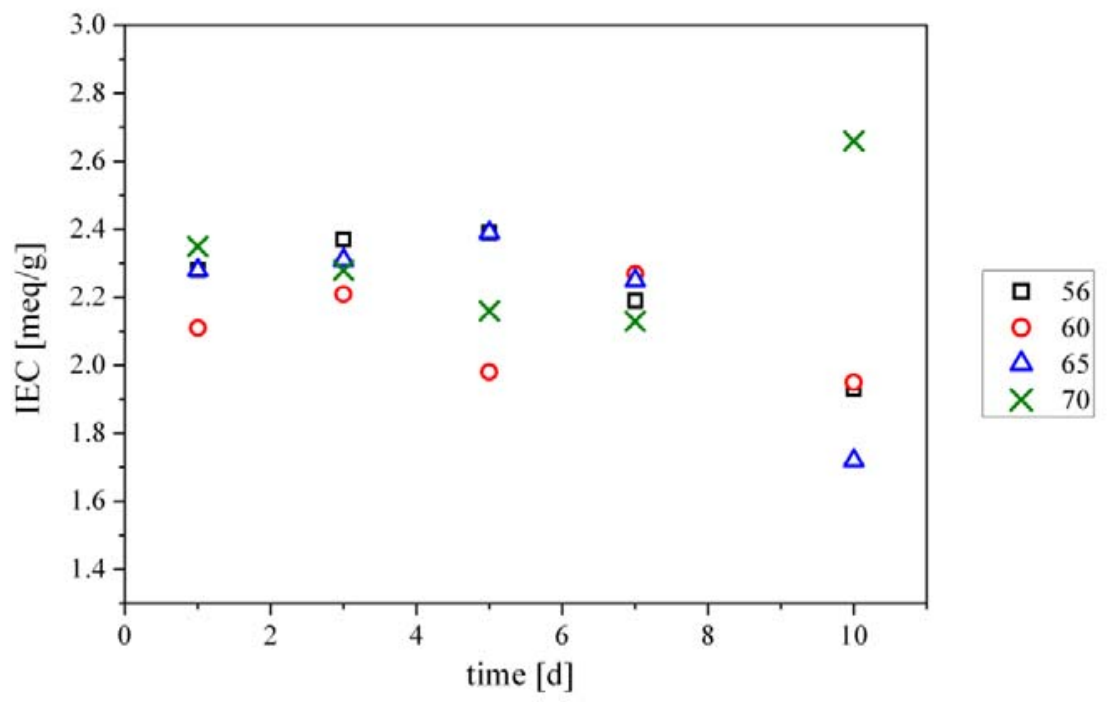

Figure 6: The IEC values after different $A E M$ immersion times in aqueous $\mathrm{KOH}(1 \mathrm{M})$ at $90^{\circ} \mathrm{C}$. The legend gives the degrees of cross-linking. 


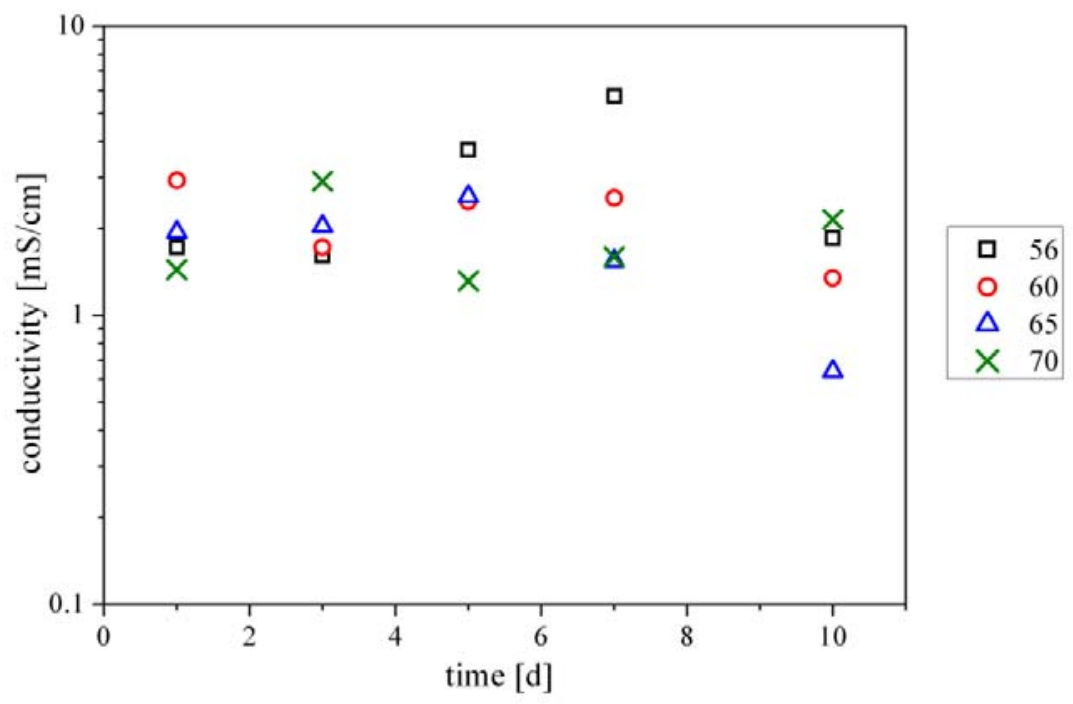

Figure 7: The ion conductivity after different AEM immersion times in aqueous $\mathrm{KOH}(1 \mathrm{M})$ at $90^{\circ} \mathrm{C}$. The legend gives the degrees of cross-linking. 


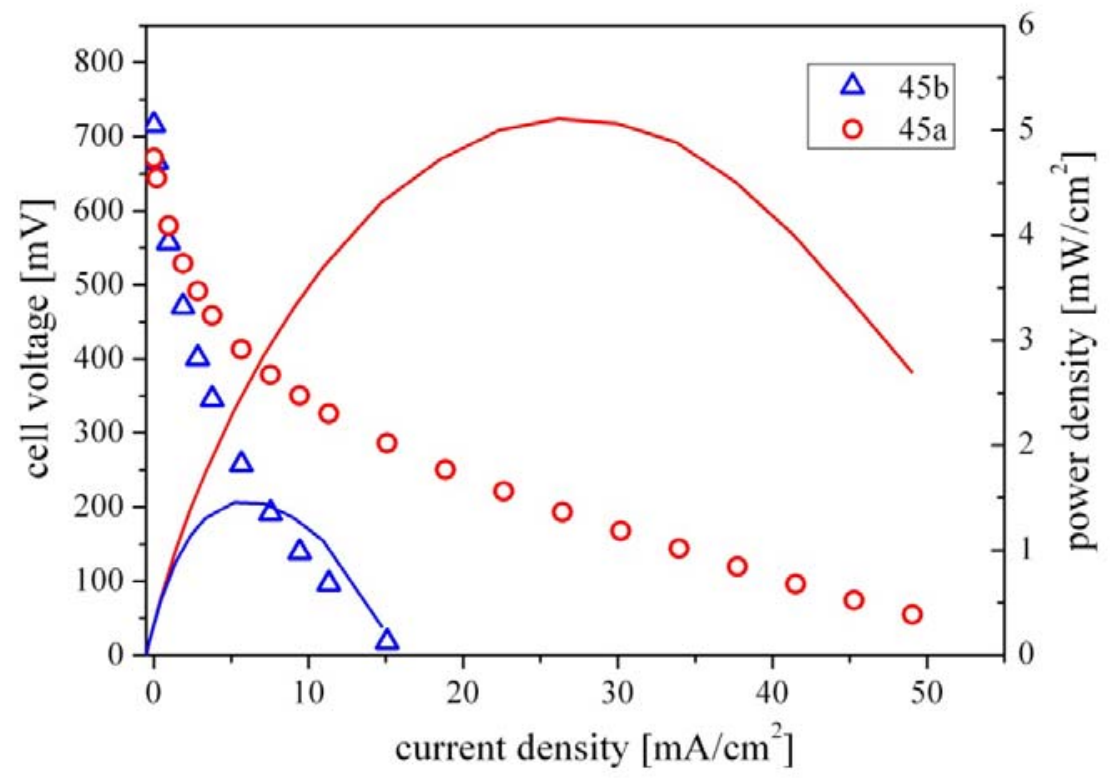

Figure 8: Cell performance at $T_{\text {cell }}=50^{\circ} \mathrm{C}$ for a MEA with a $45 \%$ covalent cross-linked membrane before (b) and after (a) solvent extraction. 


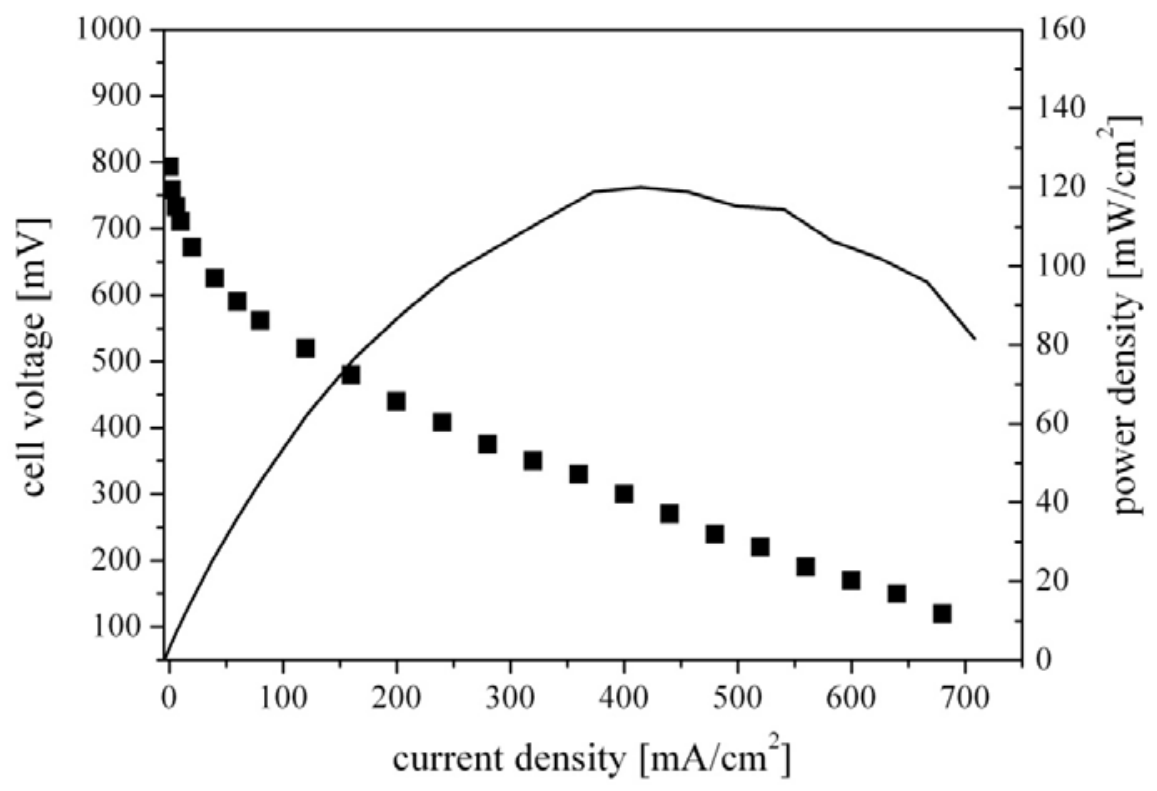

Figure 9: Cell performance at $T_{\text {cell }}=80^{\circ} \mathrm{C}$ for a $\mathrm{MEA}$ with a $37 \%$ covalent cross-linked AEM. Anode catalyst $=3020$ (Acta), cathode catalyst $=4010$ (Acta), oxidant $=$ dry oxygen, $A_{\text {cell }}=1 \mathrm{~cm}^{2}$, fuel supply $=$ aqueous MeOH (4 M) + KOH (5 M).

\section{Tables:}

Table 1: Average molecular weight of PBIOO and mPBIOO

\begin{tabular}{cccc}
\hline Polymer & $\overline{\mathrm{M}}_{\mathrm{n}}[\mathrm{Da}]$ & $\overline{\mathrm{M}}_{\mathrm{w}}[\mathrm{Da}]$ & PDI \\
\hline PBIOO & 33000 & 77000 & 2,3 \\
mPBIOO & 30000 & 103000 & 3,5 \\
\hline
\end{tabular}

Table 2: Dependence of the cross-linking degree on the solvent evaporation temperature used when casting the anion-exchange membranes

\begin{tabular}{ccc}
\hline $\begin{array}{c}\text { temperature } \\
{\left[{ }^{\circ} \mathbf{C}\right]}\end{array}$ & $\begin{array}{c}\text { cross-linking degree } \\
{[\%]}\end{array}$ & $\begin{array}{c}\text { IEC } \\
{[\mathbf{m e q} / \mathbf{g}]}\end{array}$ \\
\hline 50 & 0 & 2.6 \\
80 & 0 & 2.6 \\
100 & 56 & 2.9 \\
120 & 60 & 2.9 \\
140 & 65 & 2.4 \\
160 & 70 & 2.4 \\
\hline
\end{tabular}


Table 3: The IEC values and $\mathrm{Cl}^{-}$anion conductivities before and after the solvent extraction experiment

\begin{tabular}{ccccc}
\hline $\begin{array}{c}\text { cross-linking } \\
\text { degree } \\
{[\%]}\end{array}$ & $\begin{array}{c}\text { IEC before } \\
\text { extraction } \\
{[\mathbf{m e q} / \mathbf{g}]}\end{array}$ & $\begin{array}{c}\text { IEC after } \\
\text { extraction } \\
{[\mathbf{m e q} / \mathbf{g}]}\end{array}$ & $\begin{array}{c}\text { conductivity } \\
\text { before extraction } \\
{[\mathbf{m S} / \mathbf{c m}]}\end{array}$ & $\begin{array}{c}\text { conductivity } \\
\text { after extraction } \\
{[\mathbf{m S} / \mathbf{c m}]}\end{array}$ \\
\hline 56 & 2.9 & 2.2 & 2.5 & 2.4 \\
60 & 2.9 & 2.4 & 2.6 & 3.2 \\
65 & 2.4 & 2.4 & 2.5 & 2.2 \\
70 & 2.4 & 2.3 & 3.0 & 3.0 \\
\hline
\end{tabular}

Equation (1): $C D[\%]=\frac{w_{a}}{w_{b}} \times 100$

Equation (2): $\quad I E C_{\text {total }}=\frac{\left(V_{H C l} \times 0.1-V_{N a O H} \times 0.01\right)}{w_{d r y}}$

Equation (3): $\quad \sigma=\frac{1}{r_{s p}}=\frac{d}{R \times A}$

Equation (4): $M U[\%]=\frac{w_{w e t}-w_{d r y}}{w_{d r y}}$

\section{Methylated polybenzimidazole and its application as a blend component in covalently cross-linked anion-exchange membranes for DMFC}

Highlights:

We developed a method for methylation of polybenzimidazole without using carcinogenic agents.

We developed covalent cross-linked membranes, which were stable in alkaline medium.

DMFC performance of extracted membranes reaches very good values. 